\title{
Reduction of sediment, phosphorus and nitrogen transport on vegetated buffer strips
}

\author{
JAANA UUSI-KÄMPPÄ and TOIVO YLÄRANTA
}

\begin{abstract}
UUSFKÄMPPÄ, J. \& YLÄRANTA, T. 1992. Reduction of sediment, phosphorus and nitrogen transport on vegetated buffer strips. (Research Note). Agric. Sci. Finl. 1: 569-575. (Agric. Res. Centre of Finland, Inst. Soils and Environ., SF-31600 Jokioinen, Finland.)
\end{abstract}

\begin{abstract}
The largest source of phosphorus and nitrogen in surface waters is cultivated soils. The effects of ten-meter wide grass buffer strips (GBS) on sediment and nutrient losses from cropped soil plots have been studied for one year at the Agricultural Research Centre in Finland. The GBS plots were compared to plots without vegetated buffer strips (noVBS).

The GBSs decreased loads of total solids, phosphorus and nitrogen by an average of 23,6 and $47 \%$, respectively. The grass buffer strips were effective in autumn but not in spring. Thirty-eight percent more soluble phosphate phosphorus was leached from the GBS plots than from the plots without GBSs, because of their inefficiency in spring.
\end{abstract}

Key words: water erosion, grass buffer strip, non-point pollution, runoff

\section{Introduction}

In Finland, the relative importance of non-point pollution has increased during the last two decades. The most important nutrients carried to surface waters are phosphorus and nitrogen. At present, agriculture contributes most of the diffuse loading (REKOLAINEN 1989).

Phosphorus is the main nutrient limiting primary production in Finnish lakes. Experimental results have indicated that $75 \%$ of the phosphorus transported to watercourses is bound to sediment, and about $5 \%$ of the sediment-bound phosphorus is available for algal growth (EKHOLM et al. 1991). In total, $29 \%$ of the phosphorus load (soluble + adsorbed) is biologically available (ЕКнOLM 1992).
As a result of these findings, methods that decrease phosphorus and nitrogen losses from agricultural land are of increasing interest in Finland. These methods include cultivation practicies and vegetated buffer strips, i.e. uncultivated areas between fields and watercourses. Permanent vegetation on the strip protects the river bank from erosion and leaching (AHOLA 1990). In the United States of America, buffer strips have been shown to be effective for the removal of sediment and other suspended solids from surface runoff if the flow is shallow and uniform (MAGETTE et al. 1987, DILLAHA et al. 1989).

Since 1991 the influence of various vegetated buffer strips on nutrient loss from fields into watercourses has been studied at the Agricultural Re- 
search Centre of Finland. This paper presents the experimental results from the first year.

\section{Material and methods}

\section{Experimental field}

A 6-plot experimental field was established at the Agricultural Research Centre in Jokioinen, southern Finland $\left(60^{\circ} 48^{\prime} \mathrm{N}\right.$ and $\left.23^{\circ} 28^{\prime} \mathrm{E}\right)$ during the autumn of 1989. The soil on the experimental field contains 54-63 per cent clay (particle size $<0.002$ $\mathrm{mm})$ in the plough layer $(0-20 \mathrm{~cm})$. The ten-meter broad buffer strips are situated below the cropland source area (Fig. 1) which is flat, but the buffer strips are on a slope of $16 \%$, varying between $12 \%$ and $18 \%$.

The experimental treatments were as follows (two replicates):

1) spring grain and a $10 \mathrm{~m}$ wide grass buffer strip sown with timothy (Phleum pratense) and meadow fescue (Festuca pratensis) (GBS);

2) spring grain and no vegetated buffer strip (noVBS);

3) spring grain and a $10 \mathrm{~m}$ wide vegetated buffer strip where typical Finnish bushes, hardwood trees, and wild hay and flowers are growing (VBS).

Before the experiment the field was calibrated for one year by cultivating plots in the same way and collecting water and soil samples. The loads of runoff, total solids and nutrients varied between the plots. The differences were considered when the experiment was being established and the buffer strips were being sown on the plots (Fig. 1).

Surface and subsurface water to a depth of $30 \mathrm{~cm}$ flowed into one collector trench on each plot. The volume was measured and a representative subsample was taken for laboratory analysis.

\section{Water sampling and analysis}

Water samples of $500 \mathrm{ml}$ were collected in polyethylene bottles once a week or every second week during the runoff time. Total solids, and concentrations of total nitrogen and total phosphorus were determinated in unfiltered samples. For other determinations, samples were filtered through a membrane filter (Sartorius 11306-50-PFN, pore size $0.45 \mu \mathrm{m}$ ) before analysis.

Total solids were determined as evaporated residue after drying at $105^{\circ} \mathrm{C}$. Total phosphorus, soluble phosphate phosphorus, total nitrogen, nitrate nitrogen and ammonium nitrogen were analyzed according to the Finnish standard methods (SFS 3026, SFS 3025, SFS 3031, SFS 3030 and SFS 3032) and using Flow Injection Analysis on a LACHAT QuikChem analyzer.

\section{Results}

Surface and subsurface runoff did not vary much between plots during the calibration and experimental periods (Table 1).

Precipitation during the period when runoff occured was (Ilmatieteen laitos 1990, 1991, 1992):

- calibration year 1990/91 (2.8.1990-16.5.1991) $460 \mathrm{~mm}$

- experimental year 1991/92 (25.9.199121.4.1992) $354 \mathrm{~mm}$.

In the experimental year, the plots without the vegetated buffer strips (no-VBS) were compared only with the grass buffer strip (GBS) plots (Table 1). The plots with bushes and trees (VBS) were omitted from the comparison because the strips were poorly covered by vegetation and did not function properly.

\section{Total solids}

The loads of total solids varied over all the plots from 270 to $530 \mathrm{~kg} / \mathrm{ha}$ during the calibration and experimental years (Table 1). In the autumn of 1991, the load of total solids from the GBS plots 


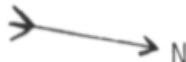

ditch $18 \mathrm{~m}$
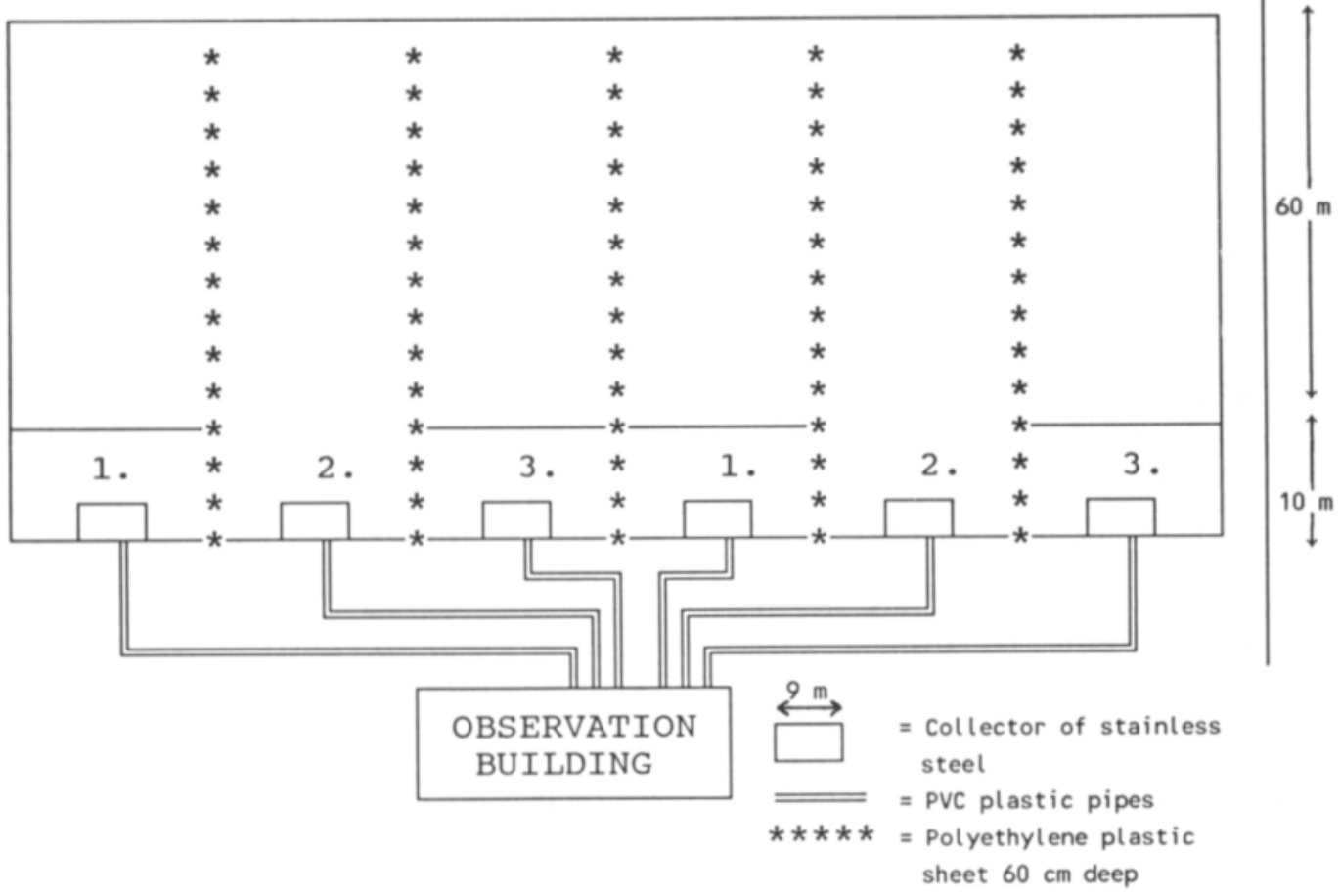

Experimental treatments:

1. Grass buffer strip (GBS); Seed mixture of timothy (Phleum pratense) $22 \mathrm{~kg} / \mathrm{ha}$ and meadow fescue (Festuca pratensis) $12 \mathrm{~kg} / \mathrm{ha}$ was sown with a companion crop of barley in May 1991. The barley was harvested in August 1991.

2. No vegetated buffer strip (no-VBS); sown with barley and fertilized like cropland source area.

3. Vegetated buffer strip (VBS); sown with common bent (Agróstis ténuis) in June 1991. Goat willow (Salix cáprea), mountain currant (Ribes alpinum), European cranberry bush (Vibúrnum ópulus), birch (Bétula), alder (Alnus), maple (Acer platanoides) and mountain ash (Sorbus aucupária) were planted in October.

The cropland source area, above the buffer strips, was sown with barley (cv. Etu) and fertilized (NPK compound fertilization: $90 \mathrm{~kg} \mathrm{~N} / \mathrm{ha}, 18 \mathrm{~kg} \mathrm{P} / \mathrm{ha}$ and $36 \mathrm{~kg} \mathrm{~K} / \mathrm{ha}$ ) in May 1991. The barley was harvested in August and the field was ploughed in September.

Fig. 1. Schematic diagram of experimental field.

was $170 \mathrm{~kg} / \mathrm{ha}$, only $51 \%$ of that from the no-VBS plots. However, in the spring the loss of suspended material from the GBS plots was $240 \mathrm{~kg} / \mathrm{ha}, 20 \%$ greater than that from the no-VBS plots. Considering the whole experimental year, the GBSs decreased total solids in the runoff water by an average of $120 \mathrm{~kg} / \mathrm{ha} \mathrm{(23 \% ).}$

\section{Phosphorus losses}

The loads of total phosphorus and soluble phosphate phosphorus were almost the same on all plots during the calibration period (Table 1). During the first experimental year phosphorus losses were greater than during the calibration period; the total load was more than doubled on the no-VBS plot. 
Table 1. Loads of surface and subsurface runoff (Total runoff), total solids (TS) and nutrients during calibration and experimental periods.

\begin{tabular}{|c|c|c|c|c|c|c|c|c|c|}
\hline \multirow[t]{2}{*}{ Period } & \multirow[t]{2}{*}{ Plots } & \multirow[t]{2}{*}{$\begin{array}{l}\text { Treat- } \\
\text { ments }\end{array}$} & \multirow{2}{*}{$\begin{array}{r}\text { Total } \\
\text { runoff } \\
(\mathrm{mm})\end{array}$} & TS & Tot-N & $\mathrm{NO}_{3}{ }^{-}-\mathrm{N}$ & $\mathrm{NH}_{4}{ }^{+}-\mathrm{N}$ & Tot-P & $\mathrm{PO}_{4}{ }^{3-}-\mathrm{P}$ \\
\hline & & & & \multicolumn{6}{|c|}{ (kg/ha) } \\
\hline \multicolumn{10}{|l|}{ Calibration } \\
\hline Autumn 1990 & & & 19 & 150 & 3.5 & 3.2 & 0.03 & 0.14 & 0.02 \\
\hline Spring 1991 & 1 & no-VBS & 44 & 220 & 2.8 & 2.4 & 0.09 & 0.16 & 0.04 \\
\hline Sum 1990/91 & & & 63 & 370 & 6.3 & 5.6 & 0.12 & 0.30 & 0.06 \\
\hline \multicolumn{10}{|l|}{ Calibration } \\
\hline Autumn 1990 & & & 15 & 100 & 3.0 & 2.8 & 0.02 & 0.10 & 0.02 \\
\hline Spring 1991 & 2 & no-VBS & 39 & 170 & 2.9 & 2.5 & 0.07 & 0.12 & 0.04 \\
\hline Sum 1990/91 & & & 54 & 270 & 5.9 & 5.3 & 0.09 & 0.22 & 0.06 \\
\hline \multicolumn{10}{|l|}{ Experimental } \\
\hline Autumn 1991 & & & 15 & 170 & 0.5 & 0.3 & 0.01 & 0.20 & 0.02 \\
\hline Spring 1992 & 1 & GBS & 61 & 240 & 1.9 & 1.4 & 0.10 & 0.27 & 0.09 \\
\hline Sum 1991/92 & & & 76 & 410 & 2.4 & 1.7 & 0.11 & 0.47 & 0.11 \\
\hline \multicolumn{10}{|l|}{ Experimental } \\
\hline Autumn 1991 & & & 16 & 330 & 2.0 & 1.4 & 0.02 & 0.30 & 0.02 \\
\hline Spring 1992 & 2 & no-VBS & 43 & 200 & 2.5 & 2.1 & 0.06 & 0.20 & 0.06 \\
\hline Sum 1991/92 & & & 59 & 530 & 4.5 & 3.5 & 0.08 & 0.50 & 0.08 \\
\hline
\end{tabular}

Whilst losses from the GBS plot were greater than those in the calibration period, the buffer strip appeared to reduce total phosphorus load by $6 \%$ overall, comprising a reduction in the autumn of 100 $\mathrm{g} / \mathrm{ha}(33 \%)$, but an increase in the spring of $70 \mathrm{~g} / \mathrm{ha}$ $(35 \%)$.

On the GBS plots $23 \%$ of total phosphorus was in the form of phosphate, but on the no-VBS plots only $16 \%$ was phosphate phosphorus. The losses of soluble phosphate phosphorus were $38 \%$ greater from the GBS plots than from the no-VBS plots, solely because of the much greater (by $30 \mathrm{~g} / \mathrm{ha}$ or $50 \%$ ) loss from the GBS plots in spring.

\section{Nitrogen losses}

During the experimental period less total nitrogen was leached than during the calibration period. Even the no-VBS plots lost $1.4 \mathrm{~kg} \mathrm{~N} / \mathrm{ha}$ less, but the
GBSs reduced losses over the previous year by 3.9 $\mathrm{kg} \mathrm{N} / \mathrm{ha}$ and over the no-VBS plots by $2.1 \mathrm{~kg} \mathrm{~N} / \mathrm{ha}$. One reason for the reduced loss from the no-VBS plots may be that the $10 \mathrm{~m}$ wide area in the slope of even the no-VBS plots was without any plant cover during the calibration year and the year before that. Obviously, quite a lot nitrogen had been mineralized during the two years and so any nitrogen moving through the strips was well-utilized.

Buffer strips also reduced nitrate losses. The load of nitrate nitrogen from the GBS plots $(1.7 \mathrm{~kg} / \mathrm{ha})$ was only half of that from the no-VBS plots (Table 1). In autumn 1991 load of nitrate nitrogen from the GBSs $(0.3 \mathrm{~kg} / \mathrm{ha})$ was over four times smaller than from the no-VGB plots. In spring 1992 the loads were higher, but difference between plots became smaller.

Loads of ammonium nitrogen were very small, and varied from $80 \mathrm{~g} / \mathrm{ha}$ on the no-VBS plots to 
$110 \mathrm{~g} / \mathrm{ha}$ on the GBS plots in the experimental year. This was because a small autumn benefit from GBSs was affect by a much larger negative effect in spring.

\section{Discussion}

In this experiment the loads of total solids were small. PUUSTINEN (1992) found loads of total solids three times larger on an experimental field near Turku in southwestern Finland during winter 19901991. In that research the runoff was also three times larger than in this experiment. MANSIKKANIEMI (1982) studied stream systems in southwestern Finland and, compared to this research, found ten times the amount of material (4000-4500 $\mathrm{kg} / \mathrm{ha}$ ) washed out from undulating arable land in a dry year. The small loss of total solids in this experiment was caused by the flatness of the experimental field which resulted in very little runoff.

Losses of phosphorus were also small in this study. PUUSTINEN (1992) found 6-7 times more total phosphorus in surface and subsurface waters only $70 \mathrm{~km}$ southwest of Jokioinen on similar soil, and TURTOLA and JAAKKOLA (1985) found a little more phophorus in surface waters from cropland in Jokioinen. In this study the amounts of total phosphorus lost were small because most phosphorus was bound to soil particles and there was not much erosion from the field.

Loads of nitrogen and nitrate nitrogen from the no-VBS plots were almost the same as those from cropland areas found by PUUSTINEN (1992) and TURTOLA and JAAKKOLA (1985). On the GBS plots the loads of nitrogen were smaller than in the other experiments in Finland.

Dillaha et al. (1989) found that in Virginia in the USA $9.1 \mathrm{~m}$ wide vegetated filter strips on $11 \%$ and $16 \%$ slopes decreased sediment and total phosphorus losses from bare cropland by an average of 84 and $79 \%$, respectively. In Maryland, MAGETTE et al. found reductions in losses of sediment and total phosphorus by $9.2 \mathrm{~m}$ wide vegetated filter strips of 86 and 53\%, respectively, from a fallowed field. In this study only the effect on nitrogen losses $(47 \%)$ was almost as large as in the USA. Decreases in losses of total solids (23\%) and total phosphorus $(6 \%)$ were much smaller. There are four possible reasons for this. Firstly this study was carried out without irrigation, whereas in the USA a rainfall simulator was used to apply $100 \mathrm{~mm}$ of rainfall to each plot over a two-day period. A rainfall intensity of $50 \mathrm{~mm} / \mathrm{h}$ was used during all simulations.

Secondly, the climate in Finland is very different from that in Virginia and Maryland. Here the soil was covered by snow in the winter. Thus, the vegetation on the GBSs did not grow during the period of main runoff in the early spring, in contrast to the sitution in the USA where the filter strips were effective throughout the whole experimental period.

Thirdly, in the USA cropland source area was fertilized and left bare before rainfall simulations. In this experiment source area was sown with barley which took nutrients from the soil during summer. Forthly, the particle size distribution of the soil in these experiments was different. The Finnish soil was finer with much more clay.

In this experiment soluble phosphate phosphorus leaching increased $50 \%$ from the GBSs in the spring. DillaHa et al. (1989) found that phosphate yields from buffer strips were often larger than the inputs to the buffers. They also indicated that there was a tendency for previously trapped phosphorus to be released from the buffer strip vegetation and soil as soluble phosphorus during later runs. In Finland TURTOLA (1990) found that leaching of soluble phosphate phosphorus increased from green fallow field during the second year of an experiment because of phosphate loss from the plants. Soluble phosphorus might also be lost from the vegetation residues on the grass buffer strips in the same way. 


\section{References}

Aноla, H. 1990. Vegetated buffer zone examinations on the Vantaa River basin. Aqua Fennica 20: 65-69.

Dillaha.t. A., Reneal R.B., mostaghimul, S. \& Lee, D. 1989. Vegetative filter strips for agricultural nonpoint source pollution control. Transactions of the ASAE 32: 513-519.

Екноцм, P. 1992. Maataloudesta peräisin oleva fosfori vesien rehevöittäjänä. In: Rekolainen, S. \& Kauppi, L. (eds.). Maatalous ja vesien kuormitus. Yhteistutkimusprojektin tutkimusraportit. Vesi- ja ympäristöhallituksen monistesarja No 359. Helsinki. p. 39-46.

—, Yli-Halla, M. \& KYlmälä, P. 1991. Availability of phosphorus in suspended sediments estimated by chemical extraction and bioassay. Verh. Internat. Verein. Limnol. 24: 2994-2998.

Ilmatieteen laitos 1990. Kuukausikatsaus Suomen ilmastoon. Nos 8-12. Helsinki.

Ilmatieteen laitos 1991. Kuukausikatsaus Suomen ilmastoon. Nos 1-5, 9-12. Helsinki.

Ilmatieteen laitos 1992. Kuukausikatsaus Suomen ilmastoon. Nos 1-4. Helsinki.

Magette, W. L., Brinsfield, R. B .,Palmer, R. E., Mood, J. D. , Dillaha, T. A. \& Reneau, R. B. 1987. Vegetated filter strips for agricultural runoff treatment. CBP/TRS 2/87. 125 p. U. S. Environmental Protection Agency.

MANSIKKANIEMI, H. 1982. Soil erosion in areas of intensive cultivation in southwestern Finland. Fennia 160: 225276.

PuUstinen, M. 1992. Peltoviljelyksestä aiheutuvan vesistökuormituksen vähentäminen. In: Rekolainen, S. \& Kauppi, L. (eds.). Maatalous ja vesien kuormitus. Yhteistutkimusprojektin tutkimusraportit. Vesi- ja ympäristöhallituksen monistesarja No 359. Helsinki. p. 107121.
Rekolainen, S. 1989. Phoshorus and nitrogen load from forest and agricultural areas in Finland. Aqua Fennica 19: 95-107.

SFS 3025 Veden fosfaatin määritys. (Finnish standard concerning determination of phosphate in water). Suomen standardisoimisliitto. Helsinki 1986. 10 p.

SFS 3026 Veden kokonaisfosforin määritys. Hajotus peroksodisulfaatilla. (Finnish standard concerning detetermination of total phosphorus in water. Digestion with peroxodisulphate). Suomen standardisoimisliitto. Helsinki $1986.11 \mathrm{p}$.

SFS 3030 Veden nitriitti- ja nitraattitypen summan määritys. (Finnish standard concerning determination of the sum of nitrite and nitrate nitrogen in water). Suomen standardisoimisliitto. Helsinki 1990. 5 p.

SFS 3031 Veden typen määritys. Peroksodisulfaattihapetus. (Finnish standard concerning determination of nitrogen in water. Oxidation with peroxodisulfate). Suomen standardisoimisliitto. Helsinki 1990.6 p.

SFS 3032. Veden ammoniumtypen määritys. (Finnish standard concerning determination of ammonia-nitrogen of water). Suomen standardisoimisliitto. Helsinki 1976. 6 p.

Turtola, E. 1990. Minskning av utlakning genom grönträda. Nordisk jordbruksforskning 72: 200.

— \& JAAKKOLA, A. 1985. Viljelykasvin ja lannoitustason vaikutus typen ja fosforin huuhtoutumiseen savimaasta. Maatalouden tutkimuskeskus. Tiedote 6/85. 43 p.

Manuscript received September 1992

\section{Jaana Uusi-Kämppä}

Toivo Yläranta

Agricultural Research Centre of Finland Institute of Soils and Environment SF-31600 Jokioinen, Finland 


\title{
SELOSTUS
}

\section{Suojakaistat eroosion ja ravinnehuuhtoutumien vähentäjinä rantapelloilla}

\author{
JAANA UUSI-KÄMPPÄ ja TOIVO YLÄRANTA
}

\author{
Maatalouden tutkimuskeskus
}

\begin{abstract}
Maatalouden tutkimuskeskuksessa Jokioisissa aloitettiin suojakaistatutkimus syksyllä 1991. Koekenttä perustettiin savimaalle. Kentän yläosa on melko tasainen, mutta suojakaistat ovat rinteessä, jonka keskikaltevuus on $16 \%$. Ensimmäisenä koevuonna selvitettiin $10 \mathrm{~m}$ leveän nurmikaistan (kylvetty timotei-nurminata) kykyä estää eroosiota ja ravinteiden huuhtoutumista pellolta. Suojakaistaruutujen valumatuloksia verrattiin ilman suojakaistaa viljeltyihin viljaruutuihin. Valumavesistä mitattiin kokonaisfosfori, liu-koinen fosfaattifosfori, kokonaistyppi, nitraattityppi, ammoniumtyppi ja haihdutusjäännös, joka kuvasi eroosion suuruutta. Valumavesien keräys alkoi syksyllä 1991 puinnin jälkeen ja loppui keväällä 1992 valunnan loputtua. Kesällä ei kerätty valumavesiä, koska valunta oli hyvin vähäistä.
\end{abstract}

Suojakaistakokeen ensimmäisen koevuoden tulokset osoittavat, että nurmikaistat vähensivät $47 \%$ kokonaistypen, $51 \%$ nitraattitypen, $6 \%$ kokonaisfosforin ja $23 \%$ eroosioaineksen huuhtoutumista. Nurmikaistat puhdistivat pintavaluntavesiä parhaiten syksyllä. Tällöin kokonaistypestä jäi $75 \%$, nitraattitypestä $79 \%$, kokonaisfosforista $33 \%$ ja eroosioaineksesta $49 \%$ nurmikaistoille. Keväällä kaistat pidättivät epäpuhtauksia huonommin. Tällöin eroosioaineksen ja fosforin huuhtoutuminen oli nurmikaistoilla suurempaa kuin ilman suojakaistaa viljellyillä ruuduilla. Liukoisen fosforin huuhtoutumisen lisääntymisen syynä saattoi olla nurmikaistojen kasvillisuuteen ja maahan pidättyneen fosforin muuttuminen liukoiseen muotoon keväällä. 